\title{
OPTIMAL AND SUITABLE CONDITIONS FOR PROSPECTIVE SPRING CAMELINA CULTIVATION IN SLOVAKIA - SCREENING BY THE SYSTEM OF SOIL CLIMATIC UNITS
}

\author{
ŠTEFAN KOCO ${ }^{1,2^{*}}$, RADOSLAV BUJNOVSKÝ ${ }^{3}$ \\ ${ }^{1}$ National Agriculture and Food Centre, Lužianky, Slovak Republic \\ ${ }^{2}$ University of Prešov, Prešov, Slovak Republic \\ ${ }^{3}$ Association Energy, Leopoldov, Slovak Republic
}

Koco, Š. and Bujnovský, R.: Optimal and suitable conditions for prospective spring camelina cultivation in Slovakia screening by the system of soil climatic units. Agriculture (Polnohospodárstvo), 67(1), 42-46.

\begin{abstract}
Camelina [Camelina sativa (L.) Crantz], a recently rediscovered oil crop is becoming of interest to both industry and farmers due to its relatively wide use. The amount of camelina seed production is / will be influenced both by the demand from the industry and by the suitable conditions that allow its profitable cultivation. A preliminary insight on optimal part of the used arable land in Slovakia suitable for growing this crop was based on available information on the environmental requirements of camelina and the system of land evaluation units of agricultural soils. These data have been acquired from database managed and continuously updated by National Agriculture and Food Centre-Soil Science and Conservation Research Institute Bratislava. From this database information concerning the climatic region, slope, soil texture, soil depth, and skeleton content were used. The obtained results show that approximately $27 \%$ of the acreage of utilised arable land has optimal quality for spring camelina cultivation in Slovakia. If camelina will be used for the production of various biobased materials, on a smaller scale (several thousand hectares) it is possible to grow this crop without a significant restriction of the cultivation of other crops, especially those intended for food and feed production. In case of camelina utilisation as a feedstock for conventional biofuels production, it is necessary to take into account its competitiveness compared to oilseed rape, which is currently the main raw material for FAME (fatty acid methyl ester) production, both in terms of profitability of cultivation and $\mathrm{CO}_{2}$ emissions per tonne of oilseed yield.
\end{abstract}

Key words: Camelina sativa (L.) Crantz, climate conditions, soil conditions, suitability of cultivation

Camelina [Camelina sativa (L.) Crantz] represents the recently rediscovered oil crop which has the potential to be used as a feedstock in biofuel production and also as the raw material for the production of various bio-based materials. In addition, the camelina meal (a by-product of oil extraction) can serve as a protein feed for farm animals (Eynck \& Falk 2013; Berti et al. 2016; Murphy et al. 2016). The aim of the paper was to obtain a preliminary insight of which part of the used arable land in Slo- vakia is optimal and suitable for growing this crop.

The selection of soil and climatic conditions affects the profitability of any crop cultivation. Recently, due attention has been paid to investigate the suitability of crop cultivation on agricultural land has been given due attention by research (e.g. Bowen \& Hollinger 2004; Vilček \& Bedrna, 2007; Holzkämper et al. 2010; Koco et al. 2020). Reference papers related to screening soil-climatic conditions suitable for camellia cultivation have been pub-

RNDr. Štefan Koco, PhD. (*Corresponding author), National Agriculture and Food Centre - Soil Science and Conservation Research Institute, Raymanova 1, 08001 Prešov, Slovak Republic. E-mail: stefan.koco@nppc.sk

RNDr. Štefan Koco, PhD., Department of Geography and Applied Geoinformatics, Faculty of Humanities and Natural Sciences, University of Prešov, 17. novembra 1, 08001 Prešov, Slovak Republic

Ing. Radoslav Bujnovský, CSc., Association Energy 21, Trnavská cesta 1033, 92041 Leopoldov

(C) 2021 Authors. This is an open access article licensed under the Creative Commons Attribution-NonComercial-NoDerivs License

(http://creativecommons.org/licenses/by-nc-nd/4.0/). 
lished by Falasca et al. (2014) and Román-Figueroa et al. (2017).

The screening of optimal and sustainable soil-climatic conditions for spring camelina cultivation witjhin used arable land of Slovakia was - based on available information on camelina's environmental requirements (Putnam et al. 1993; Zubr 1997; Crowley \& Fröhlich 1998; Strašil 2008; Falasca et al. 2014; George et al. 2015; Román-Figueroa et al. 2017 ) and the system of land evaluation units - referred to as BPEJ - (Džatko, Sobocká et al. 2009), registered in the database managed and continuously updated by the National Agriculture and Food Centre - Soil Science and Conservation Research Institute in Bratislava.

Camelina is well adapted to the areas where flax is grown (Putnam et al. 1993) and for this reason, it is also referred to as "false flax". This information is the starting point when defining the suitable conditions for growing this crop. In this regard, according to Vilček \& Bedrna (2007) the best conditions for flax cultivation are locations with an altitude of more than $400 \mathrm{~m}$ and the sum of annual total rainfall greater than $600 \mathrm{~mm}$. As for soils, the most suitable are sandy loam and loam soils with a neutral to slightly acidic soil reaction. Unsuitable are clay soils prone to crusting, stony soils, dry or, conversely, wet, and land on slopes above $7^{\circ}$.

Although camelina is often considered as a less demanding crop to site conditions and inputs (e.g. Putnam et al. 1993; Zubr 1997; Strašil 2008), compared to marginal areas, in optimal conditions with mild temperatures and adequate soil moisture are achieved higher yields (Aiken et al. 2015). In addition, in conditions where the area of arable land is constantly declining and its expansion at the expense of grassland or forest land is out of the question, regulated conventional intensification of crop production (as defined by Heaton et al. 2013) is important. This fact was considered during the projection of optimal and suitable conditions for the cultivation of this crop in Slovakia where temporal intensification of crop production is limited.

The setting of the optimal and suitable range of climatic indicators and soil properties for the cultivation of spring camelina in Slovakia is indicated in Table 1 . The unsuitable category has not been considered. Unlike the authors Vilček \& Bedrna (2007), who used a 4-level classification of land suitability for growing crops (very suitable, suitable, less suitable, and unsuitable), our attention was focused on the first two, while very suitable conditions are perceived as optimal.

Regarding climatic conditions, the most important are temperature and moisture. The temperature is important both in terms of the sum of vegetatively active temperatures (above $5^{\circ} \mathrm{C}$ ) also expressed as growing degree days (Miller et al. 2001; Krzyżaniak et al. 2019), and thus in terms of the length of the growing season, as well as in terms of the occurrence of temperature extremes (especially tropical days with temperature over $30^{\circ} \mathrm{C}$ ). Moisture is primarily related to the sum of precipitation, especially during the growing period. As stated by Holzkämper et al. (2010), while the sufficient moisture is important mainly for the vegetative phase of growth, the

$\mathrm{T}$ a

Definition of optimal and suitable environmental conditions for spring camelina cultivation from view of seed yield

\begin{tabular}{|l|c|c|c|}
\hline \multirow{2}{*}{ Indicator } & \multirow{2}{*}{$\begin{array}{c}\text { Optimal } \\
\text { conditions }\end{array}$} & Dry & Wet \\
\cline { 2 - 3 } Climatic region* & $02,05,06,07$ & $01,03,04$ & 08 \\
Slope & $<3^{\circ}$ & $<7^{\circ}$ & $1-7^{\circ}$ \\
Soil texture** & $\mathrm{SL}, \mathrm{L}$ & $\mathrm{SL}, \mathrm{L}$ & $\mathrm{LS}, \mathrm{SL}, \mathrm{L}$ \\
Soil depth & $>0.6 \mathrm{~m}$ & $>0.31 \mathrm{~m}$ & $>0.31 \mathrm{~m}$ \\
Skeleton content & $<10 \%$ & $<10 \%$ & $<25 \%$ \\
\hline
\end{tabular}

*by Džatko, Sobocká et al. (2009); **LS - loamy sand; SL - sandy loam; L - loam 
occurrence of tropical days affects the generative phase of crop growth.

Because spring camelina has a short vegetation period (up to 100 days), its cultivation in Slovakia is practically not limited by the sum of physiologically active temperature. Temperature extremes, especially temperatures above $30^{\circ} \mathrm{C}$ during the ripening phase, can reduce the seed yields significantly (Aiken et al. 2015). Due to the elimination of the rainfall excess in humid and cold areas (BPEJ climate region codes 9 and 10) and due to the occurrence of hot days in the warmest climatic region (climate region code 0 ), areas corresponding with mentioned climates are not included in the definition of suitable areas for camelina cultivation (Table 1).

As additional site indicators, the slope, soil texture, soil depth, and skeleton content were taken into account. To some extent, soil texture corresponds with moisture (its retention and availability for root system). Loamy and sandy-loam soils are considered optimal for spring camelina cultivation. Suitable are also loamy-sand soils, but their production potential tends to be lower. Clearly unsuitable are clay and wet soils due to delays in entering the land for early seeding (Sintim et al. 2016) which can affect the use of winter moisture in the soil and subsequently also increase the likelihood of tropical days occurrence during ripening as a consequence of a shift in sow- ing time. Therefore, extreme soil texture categories were primarily excluded from optimal and suitable conditions for camelina cultivation.

As the most part of the camelina root system occurs in the layer 0-0.6 m (Putnam et al. 1993; Obour et al. 2015; Gesch \& Johnson 2015), only deep $(>0.6 \mathrm{~m})$ and medium-deep $(0.31-0.6 \mathrm{~m})$ soils were considered as suitable for camelina cultivation. Because increased stone/gravel content, as well as slope over $7^{\circ}$, can reduce the crop yields (Vilček \& Bedrna 2007), lands on the slope of up to $7^{\circ}$ without skeleton $(<10 \%)$ and weakly skeletal soils $(10-25 \%)$ were classified as suitable (Table 1).

Based on the parameters listed in Table 1, approximately $27 \%$ of the acreage of utilised arable land can be considered as optimal and suitable for spring camelina cultivation in Slovakia. The spatial distribution of these areas is shown in Figure 1. The remaining area of utilised arable land is considered as less suitable and unsuitable for camelina cultivation.

As stated by Neupane et al. (2018), the main advantage of camelina as a feedstock for biofuel production, in comparison to oilseed rape, is its cultivation in conditions that are no more suitable for rapeseed. The areas, where camelina could be competitive to oilseed rape, which is currently the main raw material for FAME (fatty acid methyl ester)

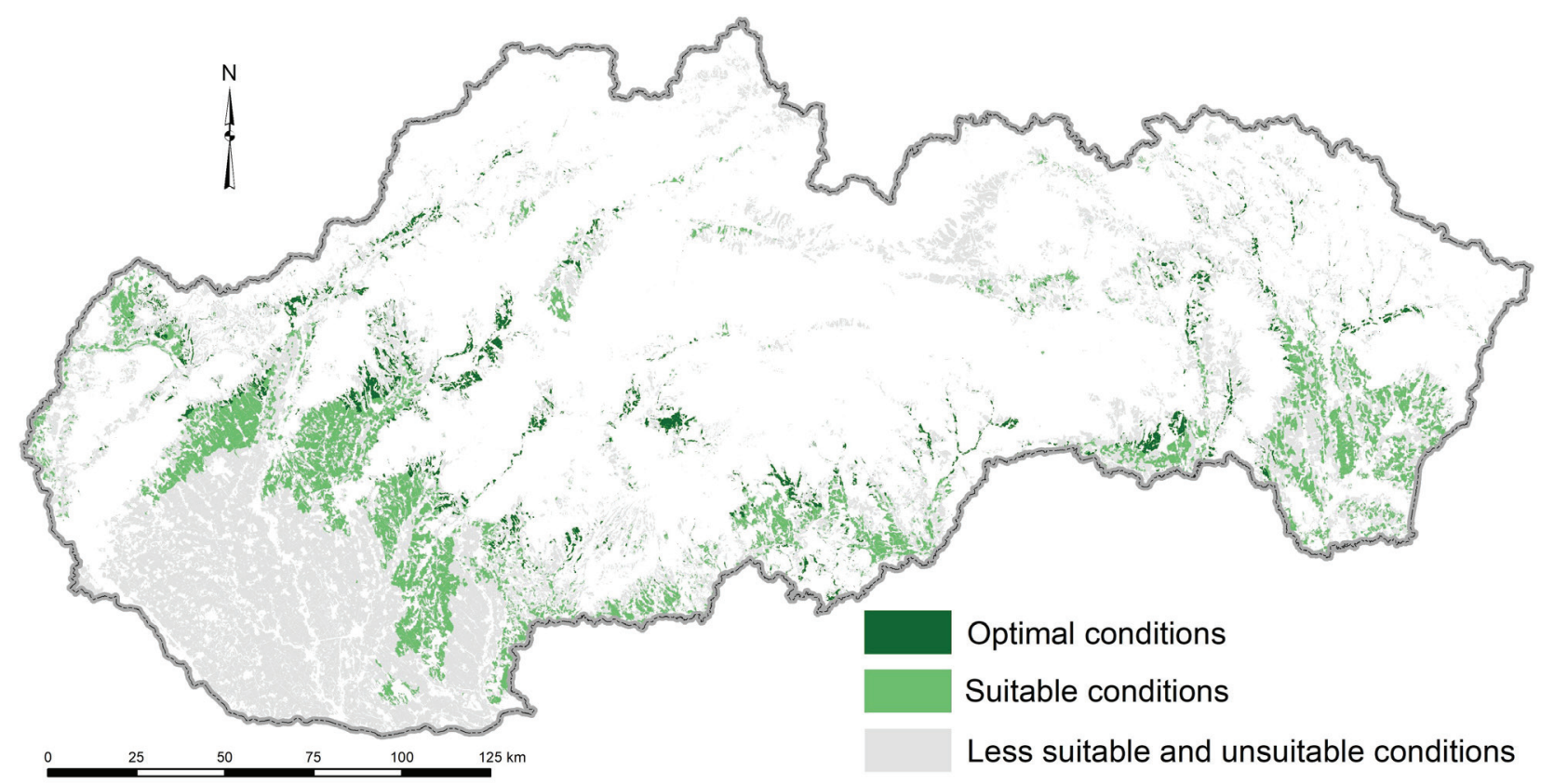

Figure 1. Optimal and suitable areas for spring camelina cultivation within the utilised arable land of Slovakia 
production, were detected by overlapping of GIS layer of optimal \& suitable areas for camelina cultivation (Figure 1) with a GIS layer of less suitable $\&$ non-suitable areas for oilseed rape (developed by Vilček \& Bedrna 2007). These areas, scattered especially in the central and eastern part of Slovakia, account for 15,000 ha.

It is reasonable to assume that in terms of cropping area the camelina may belong to the supplementary oilseeds. Its cultivation for the production of bio-based materials is practically possible within all areas defined in Figure 1. It's just obvious that the economics of camelina cultivation as well as its competitiveness to other oil crops with similar use is / will be primarily affected by the market price and seed yields per hectare (Chen et al. 2015; Li \& Mupondwa 2016; Righini et al. 2016). In the case of biofuel production, the situation is different. As indicated by Krohl \& Fripp (2012) and Bujnovský et al. (2020), decreasing $\mathrm{CO}_{2}$ emissions per tonne of feedstock (which is part of the life cycle analysis of the final biofuel), is a basic precondition of success. From this point of view, it is necessary to reduce inputs (especially nitrogenous fertilisers) and increase camelina seed yields, which basically represents the increase of inputs productivity. Preference for less humid conditions in the case of reducing $\mathrm{CO}_{2}$ emissions from cultivation is also significant in this regard.

\section{Funding}

This work was supported by the CamelGreen (project ID APVV-16-0097), USUS (project ID APVV15-0406) projects funded by Slovak Research and Scientific Grant Agency of Ministry of Education of Slovak Republic under Grant No. VEGA 1/0059/19.

\section{REFERENCES}

Aiken, R., Baltensperger, D., Krall, J., Pavlista, A. and Johnson, J. (2015). Planting methods affect emergence, flowering and yield of spring oilseed crops in the U.S. central High Plains. Industrial Crops and Products, 69, 273 -277. DOI: 10.1016/j.indcrop.2015.02.025.

Berti, M., Gesch, R., Eynck, Ch., Anderson, J. and Cermak, S. (2016). Camelina uses, genetics, genomics, production, and management. Industrial Crops and Products, 94, 690-710. DOI: 10.1016/j.indcrop.2016.09.034.

Bowen, C.R. and Hollinger, S.E. (2004). Geographic screening of potential alternative crops. Renewable Agricul- ture and Food Systems, 19(3), 141-151. DOI:10.1079/ RAFS200473.

Bujnovský, R., Holíčková, M. and Ondrejičcková, P. (2020). Spring Camelina sativa - Perspective cultivation as biofuel feedstock in Slovakia. Industrial Crops and Products, 154, 112634. DOI:10.1016/j.indcrop.2020.112634.

Chen, Ch., Bekkerman, A., Afshar, R.K. and Neil, K. (2015). Intensification of dryland cropping systems for bio-feedstock production: Evaluation of agronomic and economic benefits of Camelina sativa. Industrial Crops and Products, 71, 114-121. DOI:10.1016/j.indcrop.2015.02.065.

Crowley, J.G. and Fröhlich, A. (1998). Factors affecting the composition and use of camelina. Teagasc Project Report No. 4319. Dublin: Crop Research Centre, Teagasc, 19p.

Džatko, M., Sobocká, J. et al. (2009). Guidance for the use of maps of soil ecological units. Bratislava: Soil Science and Conservation Research Institute, 102p. (in Slovak).

Eynck, C. and Falk, K.C. (2013). Camelina (Camelina sativa). In Singh, B.P. (Ed.) Biofuel crops: Production, physiology and genetics, $1^{\text {st }}$ ed. Wallingford: CAB International, pp. 369-391.

Falasca, S.L., del Fresno, M.C. and Waldman, C. (2014). Developing an agro-climatic zoning model to determine potential growing areas for Camelina sativa in Argentina. QScience Connect, 2014(1). DOI:10.5339/connect.2014.4.

George, N., Hollingsworth, J., Levers, L., Thompson, S. and Kaffka, S. (2015). Canola and camelina: winter annual oilseeds as alternative crops for California. University of California Division of Agriculture and Natural Resources. Available at: https://ucanr.edu/sites/oilseeds/ files/211682.pdf [Accessed 12.04.2021].

Gesch, R.W. and Johnson, J.M.F. (2015). Water use in camelina-soybean dual cropping systems. Agronomy Journal, 107(3), 1098-1104. DOI:10.2134/agronj14.0626.

Heaton, E., Schulte-Moore, L., Helmers, M., Liebman, M. and Milster, F. (2013). Producing food, feed and energy: How can agriculture do it all? Proceedings of the $25^{\text {th }} \mathrm{An}$ nual Integrated Crop Management Conference. Ames: Iowa State University, pp. 33-47.

Holzkämper, A., Calanca, P. and Fuhrer, J. (2010). Evaluating climate suitability for agriculture in Switzerland. In Swayane, D.A., Wanhong Yang, Voinov, A.A., Rizzoli, A. and Filatova, T. (Eds.) Modelling for environment's sake: Proceeding of the iEMSs 2010 Conference. Ottawa, Canada. Available at: https://www.iemss.org/publications/conference/proceedings-of-the-iemss-2010-conference/ [Accessed 08.04.2021].

Koco, Š., Vilček, J., Torma, S., Michaeli, E. and Solár, V. (2020). Optimising potato (Solanum tuberosum L.) cultivation by selection of proper soils. Agriculture, 10, 155 . DOI:10.3390/agriculture10050155.

Krohn, B.J. and Fripp, M. (2012). A life cycle assessment of biodiesel derived from the „niche filling“ energy crop camelina in the USA. Applied Energy, 92, 92-98. DOI: 10.1016/j.apenergy.2011.10.025.

Krzyżaniak, M., Stolarski, M., Tworkowski, J., Puttick, D., Eynck, Ch., Załuski, D. and Kwiatkowski, J. (2019). Yield and seed composition of top spring camelina genotypes cultivated in the temperate climate of Central Europe. Industrial Crops and Products, 138, 111443. DOI:10.1016/j.indcrop.2019.06.006.

Li, X. and Mupondwa, E. (2016). Production and value-chain integration of Camelina sativa as dedicated bioenergy feedstock in the Canadian prairies. In Faaij, A.P.C., Baxter, D., Grassi, A. \& Helm, P. (Eds.) Setting the course for a biobased economy: Papers of the 24th European 
Biomass Conference and Exhibition, Amsterdam 6-9 June, pp. $151-157$. Available at: http://www.etaflorence. it/proceedings/?detail $=12482$ [Accessed 09.04.2021].

Miller, P., Lanier, W. and Brandt, S. (2001). Using growing degree days to predict plant stages. Montguide MT200103 AG 7/2001. Bozeman: Cooperative Extension Service, Montana State University, 8p. Available at:https://landresources.monana.edu/soilfertility/documents/PDF/pub/GDDPlantStagesMT200103AG.pdf [Accessed 09.04.2021].

Murphy, E.J. (2016). Camelina (Camelina sativa). In McKeon, Th., Hayes, D., Hildenbrand, D. \& Weselake, R. (Eds.) Industrial oil crops, $1^{\text {st }}$ ed. Amsterdam: AOCS, UrbanaElsevier Inc., pp. $207-230$.

Neupane, D., Solomon, J.K.Q., Davison, J. and Lawry, T. (2018). Nitrogen source and rate effects on grain and potential biodiesel production of camelina in the semiarid environment of northern Nevada. CGB Bioenergy, 10, $861-876$.

Obour, A.K., Sintim, H.Y., Obeng, E. and Jelizjakov, V.D (2015). Oilseed Camelina (Camelina sativa L. Crantz): Production systems, prospects and challenges in the USA Great Plains. Advances in Plants and Agricultural Research, 2(2), 00043. DOI: 10.15406/apar.2015.02.00043.

Putnam, D.H., Budin, J.T., Field, L.A. and Breene, W.M. (1993). Camelina: A promising low-input oilseed. In Janick, J. \& Simon, J.E. (Eds.) New crops. New York: Wiley, pp. $314-322$.
Righini, D., Zanetti, F. and Monti, A. (2016). The bio-based economy can serve as the springboard for camelina and crambe to quit the limbo. $O C L, 23(5), \mathrm{D} 504$. DOI: $10.1051 / \mathrm{ocl} / 2016021$.

Román-Figueroa, C., Padilla, R., Uribe, J.M. and Paneque, M. (2017). Land suitability assessment for camelina (Camelina sativa L.) development in Chile. Sustainability, 9, 154. DOI:10.3390/su9010154.

Sintim, H.Y., Zhelizjakov, V.D., Obour, A.K., Garcia, A.G. and Foulke, Th.K. (2016). Evaluating agronomic responses of camelina to seeding date under rain-fed conditions. Agronomy Journal, 108(1), 349-357. DOI: 10.2134/agronj2015.0153.

Strašil, Z. (2008). Basics of camelia cultivation and possibilities of its use. Guideline for practice. Prague: Research Institute of Crop Production, 21p. (in Czech).

Vilček, J. and Bedrna, Z. (2007). Suitability of agricultural soils and landscape of Slovakia for growing of plants. Bratislava: Soil Science and Conservation Research Institute, 244p. (in Slovak).

Zubr, J. (1997). Oil-seed crop: Camelina sativa. Industrial Crops and Products, 6(2), 113-119. DOI:10.1016/ S0926-6690(96)00203-8.

Received: April 29, 2021

Accepted: June 3, 2021 